\title{
Social Capital: Strategy of Takmir of Jogokariyan Mosque on Developing the Worshipers
}

\author{
Wahyu Panca Hidayat ${ }^{1}$ \\ ${ }^{1}$ GAPURA community of Yogyakarta, Yogyakarta, Indonesia. \\ Email: pancazumbon@gmail.com
}

\begin{abstract}
:
This paper discusses a phenomenon of mosque's worshipers as a social capital. Jogokariyan Mosque is, named after the village, located in Special District of Yogyakarta, Indonesia, and has a dynamic worshiper based on its activities. Dynamic because its activities could establish trustworthiness among them. Historically, existence of Muhammadiyah, as an Islamic dakwah body, since 1960s constructs norms that refer to Islamic values. The length of existence of Muhammadiyah movement builds unique networking among the alumni of Takmir of Jogokariyan Mosque, which then is used to support mosque's movements. Thus, social capital analysis based on Robert $D$. Putnam's perspective, which contains norms, networks, and trust is relevant to draw social capital phenomenon in Jogokariyan village with mosque as the key of this movement.
\end{abstract}

Keywords: Mosque, Social capital, Jogokariyan.

\section{A. INTRODUCTION}

In Muslim history, mosque is bonding among society. Mosque overcomes social problems. Mosque is able to be indicator of Muslim habit, the more intimate they're embedded to Islamic values means that they have highly response of God's orders. Because of that, in the past, mosque became information center and the place that Muslim could discuss to solve problems of social, economic and politic.

Mosque is an information center and symbol of mass integrity, which is used as a tool for developing society. Mosque is not only used to be a place to pray but also a school for muslim, a meeting point, a tribal multi-purpose room, setting up public policy and a congress room to held a governmental discussion.

Jogokariyan Mosque is under Special District of Yogyakarta's area and it has a great story. The history started of a small langgar (an Islamic boarding school) in outskirts of Jogkariyan. After years, in 1966, pupils who studied in langgar rising gradually and inhabitant alongside the Karangkajen's Muhammadiyah members sat up a team to establish a mosque. The next year, in 1967, mosque just was opened named after the village, Jogokariyan.

The activities that are hold in the mosque quite bit similar with the other mosques. The differences will be seen when a time for shalat coming. If the worshipers in another mosque is mostly always in small number, then in Jogokariyan will full. 
The number of the worshipers arose in between 2003 to today because of the accuracy of the strategy by Takmir of Jogokariyan Mosque. A revolutionary system was started in 2003 by engaging the youth and local stakeholders in the structure of Takmir. In this case, the stakeholders refered to $\mathrm{RT}$ and RW. This is a great strategy in organizing the mass community, in sociology, it called a social capital.

\section{B. METHODS}

The methodology used is descriptive qualitative analysis. Qualitative research is a study only describes the state of the object associated with the object under study are discussed in the study. This type of research is used to examine the condition of natural objects (as his opponent is an experiment), where the researcher is a key instrument.

In this section argued that, in a qualitative study, primary data collection techniques were observation, in-depth interviews, document study, and the three combined or triangulation. It should be noted that the technique of collecting data by observation, it is worth noting what is observed, when interviewed, to whom will conduct the interview.

\section{RESULT AND DISCUSSIONS}

\section{Jogokariyan Mosque}

Jogokariyan Mosque is located in jalan Jogokariyan No 36, Jogokariyan village, Mantrijeron, Yogyakarta, Indonesia. Based on data from BPS in 2010 depicted Mantrijeron inhabitant is 8,719 people. Dakwah (activities for influencing people to be a muslim) territories of Jogokariyan Mosque covered 3,970 people or 887 families. Jazir, as the head of Takmir of Jogokariyan Mosque, said that there were 280 poor families and 68 orphans.

Its history, in 1970's Jogokariyan was a village of batik traders. The traders and batik makers in Yogyakarta were Jogokariyan's; this was the reason why Jogokariyan's were well-being people. After printing batik invented, finally they broke because cannot run their business anymore. Their children were not able to survive by themselves due to they did not go to school and they became a small seller now.

\section{Scenario Planning}

Takmir sat up scenario planning. It was made in 2000 , after the first PEMILU (election) of Takmir hold. Muhammad Jazir was voted at the election. He became the head of Takmir for 3 periods, each period consists 5 years. Jazir with his men wrote 3 scenario plannings. The duration of each scenario planning is 5 years.

Generally, it can be divided in 3 periods of time. The first period is in 2000-2005. The second period is 2006-2010. And the last period is 2011-2015. Every single period had its own targets with similar indicator in each period. The table below shows the scenario planning:

\begin{tabular}{|l|l|l|l|}
\hline No & Target & Period & Indicator \\
\hline 1 & $\begin{array}{l}\text { Jogokariyan } \\
\text { Islami }\end{array}$ & $2000-2005$ & $\begin{array}{l}- \text { Transforming the society from abangan to be the } \\
\text { Islamic society. } \\
- \text { The youth who used to drunk tied up to the } \\
\text { mosque. }\end{array}$ \\
\hline
\end{tabular}




\begin{tabular}{|c|c|c|c|}
\hline & & & $\begin{array}{l}\text { - Urging inhabitant for praying (shalat [ar:șaläh]). } \\
\text { - Bonding the children in mosque. } \\
\text { - People who tend to pray in their own house are } \\
\text { invited to pray in mosque. } \\
\text { - To set the drunker as a security service of the } \\
\text { mosque. }\end{array}$ \\
\hline 2 & $\begin{array}{l}\text { Jogokariyan } \\
\text { Darusalam I }\end{array}$ & $2005-2010$ & $\begin{array}{l}\text { - Driving people to establish and to run their } \\
\text { community in mosque. } \\
\text { - Jama'ah of shalat subuh (dawn pray) go up to } \\
50 \% \text { of Jama'ah of shalat jumat (Friday pray). } \\
\text { - Creating a well-being society by using lumbung } \\
\text { masjid (mosque's fund), wide spreading health } \\
\text { service freely, giving scholarship for students and } \\
\text { loan for small traders (non-interest loan). }\end{array}$ \\
\hline 3 & $\begin{array}{l}\text { Jogokariyan } \\
\text { Darusalam II }\end{array}$ & $2010-2015$ & $\begin{array}{l}\text { - Rocketing people's sense related to Islamic } \\
\text { values. } \\
\text { - Totally urging people who prefer praying in their } \\
\text { house to be a worshiper. } \\
\text { - Increasing the jama'ah of shalat subuh (dawn } \\
\text { pray) up to } 75 \% \text { of jama'ah of shalat jumat (Friday } \\
\text { pray). } \\
\text { - involving ex-drunker becomes mosque officers or } \\
\text { volunteer of mosque's programs. }\end{array}$ \\
\hline
\end{tabular}

\section{Social Capital as a Strategy: A Putnam's Perspective}

Robert Putnam, an American politics, said social capital here refers to features of social organization, such as trust, norms and networks that can improve the efficiency of society by facilitating coordinated action. Whereas physical capital refers to physical objects and human capital refers to properties of individuals, social capital refers to connections among individuals-social networks and the norms of reciprocity and trustworthiness that arise from them. In that sense social capital is closely related to what some have called "civic virtue." The difference is that "social capital" calls attention to the fact that civic virtue is most powerful when embedded in a dense network of reciprocal social relations. A society of many virtuous but isolated individuals is not necessarily rich in social capital. Like other forms of capital, social capital is productive, making possible the achievement of certain ends that in its absence would not be possible.

\section{Networks}

The strategy which is done by Takmir of Jogokariyan Mosque for increasing the number of its worshipers is using networks they have. The networks that they have is quite large, this is because they have a good cadre system. It starts from junior high school to the professional. Cadre system is as a backbone, which plays vital keys, and forming good cadres is necessity for organization that has future goals. The cadre organization, mostly, has good quality of its members. This is caused by its intensive maintenance and controllable of the members, which is done by Takmir of Jogokariyan Mosque.

Supporting the strategy to develop its worshipers, Takmir applied recruitment openly, not only using officers of 18 RT and 4 RW but also urging people who have particular skills to be a part of Takmir. 
These strategies mean to attract more citizens to come to mosque for praying. Takmir recruit them mostly from the alumni of RMJ (Remaja Masjid Jogokariyan), the youth who become Takmir of Jogokariyan since junior high school. Even though they have moved in several places, takmir always tries to engage them in any program. This step could keep in touch between takmir and its alumni.

Different approach is given based on people's class and economic. The rich will get special approach. They are going to be invited in kajian (Islamic tradition to share its values) with particular topics such as how to spend their wealth and what is the impact they get if they do it through Islamic beliefs. The kajian is hold in the richest or most well-known people's house in village.

Implementation of kajian with particular topic aims to raise awareness of charity or donation among the rich people who live in Jogokariyan. Takmir of Jogokariyan Mosque undertakes such a strategy is not without reason; one of the fundamental reasons is to achieve scenario planning that had been made since 2000. Based on the planning, they have to rocket the Subuh worshipers up to $20 \%$ from the Friday prays and to increase muzakkī (people who must pay zakah) up to $15 \%$ of the population.

The number ofincreasing muzakkiwillaffectthe amount ofdonations, which will be, collected bythe Jogokariyan Mosque. It will be usedtodevelopthe congregationitself. In addition, since 2000Takmir of Jogokariyan Mosquelaunched infak mandiri program (self-paid cost-needed for pray) that played a major role in financial revenues. In general, since1999 the number of donations received Jogokariyan Mosque was constantly increasing.

Increasing acceptance, the infak of congregation started in 2000, which was growing annually. The infak mandiri program caused this positive trend. The Infak is a persuasive program to arouse awareness of the congregation to be willing to set aside a portion of his property for the benefit of the mosque. Upon receipt of infak increased, takmir also uses the money to improve services to the congregations. This makes the congregations continues to pay infak to the mosque until now.

\begin{tabular}{|l|l|lr|}
\hline No & Period & \multicolumn{2}{|l|}{ Amount (per year) } \\
\hline 1 & Before 1999 & IDR $\quad 8,640,000,-$ \\
\hline 2 & $2000-2004$ & IDR $43,200,000,-$ \\
\hline 3 & $2004-2006$ & IDR $95,720,000,-$ \\
\hline 4 & $2006-2008$ & IDR $225,000,000,-$ \\
\hline 5 & $2010-2011$ & IDR $113,908,500,-$ \\
\hline 6 & $2011-2012$ & IDR $579,452,000,-$ \\
\hline 7 & $2012-2013$ & IDR $1,478,050,000,-$ \\
\hline
\end{tabular}

Table of infak

\section{Norms}

In general, Takmir of Jogokariyan Mosque is not too much to use the existing norms in society as a catalyst of the strategy in the development of the congregation. It is caused by a general norm that has been previously established largely in accordance with Islamic rules. Norms in Islam are used as a tool to invite people. Prevalently, Yogyakarta's inhabitant present Jatilan culture (traditional culture) and the other kejawen culture (culture associated with javanese myth), which is against of Islamic law. But at Jogokariyan society it does not appear. 
The suitability of the general norm in the society, it is in accordance with the rules of Islam because of the presence of Muhammadiyah propaganda since the 1960s. Da'wah of Muhammadiyah originated from setting up pengajian to build the mosque.

\section{Trust}

Generally, it can be concluded that the strategies of Takmir in developing its worshipers are services. Services are sine qua non for existence of organization. Good organization serves their members well and will get the trust from them. Mosque, upon its history, had responsibility-treating umat (Islamic society).

There are a number of services that have been applied by Takmir. They can be divided in 3 kinds; spiritual services, social services and economic services. Each service will be explained below.

\section{Spiritual Services}

Spiritual services intended to bring worshipers focus in worship. The services consist many kinds, such as competition of keaktifan berjamaah (praying achievement), Ramadhan festival, society market, drum parade, bicycle festival, Taraweeh competitions, replacement sandals/shoes were missing, the food distribution for free after subuh, breakfast, coffee or milk after the dawn prayer and the most prestigious is competition of hafalan qur'an (memorizing the holy Koran) with Umrah as its prize.

The sandals/shoes replacement seems small things, but the impact is quite huge. The worshipers feel much freely on praying. Sandals/shoes which were gone replaced as its brand both in the form of goods or cash equivalent to the purchase price. The food distribution for free were started by separating coupons in the previous day. The vouchers can be exchanged for food only after Subuh sharply.

Breakfast after morning pray intended to the worshipers of more excited to come and follow the lectures after subuh. Kajian which is made by Takmir has a plenty of topics, for instance teenagers, young mothers, family and Hajj (the rich/muzakki ). The given material is different, according to participants. For example, kajian UMIDA (Umi-umi Muda/ young mothers) carried out two times, there are soft skills such as cooking and making crafts and the other is sharing islamic values to empower their islamic understanding.

Competition of keaktifan berjamaah held two times a year, each runs for four months. The competition is supported by the fingerprints tool to accurate data input. Memorizing special surah from the holy Koran is prized umrah and it is also hold twice a year.

\section{Social Services}

Social services intended for doubling activities in mosque whether it is individual or community and set mosque as a center of people's activities. Social services are performed by Takmir including volunteer of Mosque, sports, free-checking health, lodging, kurban (slaughtering sacrificial animals) and Cleaning-up teams for cleaning mosque around Jogjakarta.

Volunteers of Mosque will be sent whenthere arenatural disaster to help people. They who aresentusually haveparticularskills for instance, doctors, veterinarians, medical, orothersas 
required. Communities arealsomade to attract residents to the mosque, such as DJAMBUL community (community of bicycle).

Since 2005, Jogokariyan Mosque has had an Islamic Center and hotel. Islamic Center is used to organize various trainings and gatherings of citizens. The buildings are often rented, except for political parties and extremist organizations. While the hotel, in addition to lease for commercial purposes, is also often used as accommodation for Jogokariyan's relatives who come to visit. If there are outsiders who stay at the hotel then they will be charged as their willing, but if the user is the relatives of local residents so free of charge.

Sports such as football, futsal and badminton held regularly. Futsal and football are generally followed by young people and provided a special club called MU (Muslim United). Badminton is usually more diverse, followed by a child to adult. Slaughtering and distributing sacrificial animals' meat are hold annualy, in 2013 the mosque slaughtered 38 cows and 18 lambs.

Cleaning-up team (BBM Team) was anewprograminitiated sinceNovember 2013. BBM team is asked to clean mosques around Jogjakarta free of charge. A mechanism, which is done through a written request, telephone or text. BBM team is supported by one unit Luxiocar to facilitate its mobilization.

\section{Economic Services}

Economic servicesare initiated to guarantee the prosperity of routine worshipers. This services includedistribution of rice, low-cost market, non-interest loan anddebtalleviation. Distribution of rice is hold every 15 days for the poorand orphans. Distributed ricecomes fromdonation of the citizen. The bazaar is hold while food prices rose in market.

Non-interest loanis aimed for non-well-being people to increase their annual income. This is given in the formof goods, not money. When they earn enough profit, they have to return it, but if they got bankrupt, they do notoblige to return. Debtreductionis purposedto the peoplewho owe in moneylenders. Thisprogram is in cooperation with BankMuamalat.

\section{CONCLUSION}

The service is sine qua non for any organizations. The high-quality services effect human sense of loyalty. Mosque is everything for muslim because mosque is not only a praying place but society gathering place as well. Takmir of Jogokariyan Mosque draw how to realize it properly. The programs made and done, by the Takmir, touch vital aspect of society that could attract them to be an active mosque's worshipers.

The services given by Takmir reach 3 aspects: spiritual, social and economy. Spiritual services aim to present a peaceful condition to pray for the worshipers. Social services set society to held activities in mosque. Economic services help worshipers to be a well-being inhabitant. 


\section{References}

Abaza, Mona. (1999). Pendidikan Islam dan pergeseran orientasi: Studi kasus alumni Al-Azhar. Jakarta: LP3ES.

Abdullah, Taufik. (1987). Islam dan masyarakat: Pantulan sejarah Indonesia. Jakarta: LP3ES.

Abushouk, Ahmed Ibrahim. (2001). A Sudanese scholar in the diaspora: Life and career of Ahmad Muhammad al-Surkitti in Indonesia (191l-1943). Studia Islamika, 8 (1), pp. 55-86.

Abushouk, Ahmed Ibrahim. (2007). Al-Manar and Hadrami elite in the Malay-Indonesian world: Challenge and response. Journal of Royal Asiatic Society, Series 3, 17(3), pp. 301-322.

Al-Attas, Syed Naquib. (1991). The concept of education in Islam: A framework for an Islamic philosophy of education. Kuala Lumpur: ISTAC.

Al-Faruqi, Ismail Raji. (1982). Islamization of knowledge: General principles and workplan. Herdon, Virginia: IIIT.

Al-Faruqi, Ismail Raji. (1988). Islam, source and purpose of knowledge. Herdon, Virginia: IIIT.

Azra, Azyumardi. (1999). The transmission of al-Manar's reformism to the Malay-Indonesian world: The cases of al-Imam and al-Munir. Studia Islamika, 6(3), pp. 75-100.

Benda, H.J. (1958). The crescent and the rising sun. The Hague: W. van Hoeve Ltd.

Crawfurd, John. (1820). History of the Indian archipelago, containing an account of the manners, arts, languages, religions, institutions, and commerce of its inhabitants, Vol. II. Edinburgh: Archibald Constable and Co. Cited from Ricklefs, M.C. 2007. Polarising Javanese society: Islamic and other visions c. 1830-1930. Leiden: KITLV Press, pp. 10-11.

Dhofier, Zamakhsyari. (2011), Tradisi pesantren: Studi pandangan hidup kyai dan visinya mengenai masa depan Indonesia. Jakarta: LP3ES.

Djajadiningrat, Hoesein. (1913). Critische beschouwing van de sadjarah Banten. Haarlem. Cited from van Bruinessen, Martin. 1995. Kitab Kuning, pesantren dan tarekat: Tradisi-tradisi Islam di Indonesia. Bandung: Mizan, pp. 42.

Ember, Carol R. \& Ember, Melvin. (1994). Konsep Kebudayaan. In T. O. Ihromi (ed.), Pokok-Pokok Antropologi Budaya. Jakarta: Yayasan Obor Indonesia. Cited from Sutiyono. 2010. Benturan budaya Islam: Puritan dan sinkretis. Jakarta: Kompas.

Feillard, Andree. (2011). The constrain place of local tradition: The discourse of Indonesian traditionalist ulama in 1930s. In Michel Pikard and Remy Madinier (eds.), The politics of religion in Indonesia: Syncretism, orthodoxy, and religious contention in Java and Bali. New York: Routledge.

Geertz, Clifford. (1968). Islam observed. New Haven \& London: Yale University Press.

Geertz, Clifford. (1973). The interpretation of culture. New York: Basic Books Inc. 
Geertz, Clifford. (1976). The religion of Java. Chicago \& London: The University of Chicago Press.

Geertz, Clifford. (2001). Near East in the Far East on Islam in Indonesia. Paper Number 12, Unpublished paper.

Geertz, Cliffort. (1961). Review of the book The emergence of the modern Indonesian elite, by Robert van Niel. American Anthropologist, New Series, 63 (3), pp. 604-606.

Hebermas, Jurgen. (1991). The structural transformation of the public sphere: An inquiry into a category of buorgeois society. Massachusetts: MIT Press.

Johns, Anthony H. (1993). Islamization in Southeast Asia: Reflections and reconsiderations with special reference to the role of sufism. Southeast Asian Studies, 31(1), pp. 43-61.

Kahfi, Erni Haryanti. (2001). Islam and nationalism: Agus Salim and nationalist movement in Indonesia during the early twentieth century. Jakarta: Logos Wacana IImu.

Korver, A.P.E. (1985). Sarekat Islam: Gerakan Ratu Adil? Jakarta: Grafiti Press.

Latif, Yudi. (2008). Indonesian Muslim intellegensia and power. Singapore: ISEAS.

Lukas, Helmut. (2002). The perception of indonesia's history and culture by Western historians and social scientists. Brussels: Unpublished Seminar Paper.

Madjid, Nurcholish. (2013). Islam, kemoderenan dan keindonesiaan. Bandung: Mizan.

Nasution, S. (2001). Sejarah pendidikan Indonesia. Jakarta: Bumi Aksara.

Nazwar, Akhria. (1983). Ahmad Khatib: Ilmuwan Islam di permulaan abad ini. Jakarta: Pustaka Panjimas.

Noer, Deliar. (1973). The modernist Muslim movement in Indonesia 1900-1942. Kuala Lumpur: Oxford University Press.

Noer, Deliar. (2000). Partai Islam di pentas nasional: Kisah dan analisis perkembangan politik Indonesia 1945-1965. Bandung: Mizan.

Pranowo, Bambang. (2011). Memahami Islam Jawa. Jakarta: Pustaka Alvabet.

Raffles, Thomas Stamford. (1830). The history of Java, Vol. 2. London: John Murray. Cited from Ricklefs, M.C. (2007), Polarising Javanese Society: Islamic and other visions c. 1830-1930. Leiden: KITLV Press, pp. 10-11.

Raharjo, Supratikno. (2002). Peradaban Jawa: Dinamika pranata politik, agama, dan ekonomi Jawa kuno. Jakarta: Komunitas Bambu.

Ricklefs, M.C. (2001). A history of modern Indonesia since c. 1200. California: Stanford University Press. 
Ricklefs, M.C. (2007). Polarising Javanese Society: Islamic and other visions c. 1830-1930. Leiden: KITLV Press.

Ricklefs, M.C. (2008). Religious reform and polarization in Java. ISIM Review, vol. 21/Spring.

Ricklefs, M.C. (2013). Mengislamkan Jawa: Sejarah Islamisasi di Jawa dan penentangnya dari 1930 sampai sekarang. Jakarta: Serambi.

Shiraishi, Takashi. (1990). An age in motion, popular radicalism in Java 1912-1926. Ithaca and London: Cornell University Press.

Suminto, Aqib. (1985). Politik Islam Hindia Belanda. Jakarta: LP3ES.

Susen, Simon. (2011). Critical notes on Habermas's theory of the public sphere, Sociological Analysis, 5 (1).

Taylor, Jean Gelman. (2003). Indonesia: Peoples and histories. New Haven and London: Yale University Press.

van Bruinessen, Martin. (1995). Kitab Kuning, Pesantren Dan Tarekat: Tradisi-tradisi Islam di Indonesia. Bandung: Mizan.

van Niel, Robert. (1960). The emergence of modern Indonesian elite. Chicago: Quadrangle Book.

von Geusau, W.H. Alting. (1917). Neutraliteit der overheid in de Nederlandsche kolonien jegens godsdientzaken. Haarlem. Cited from Suminto, Aqib. 1985. Politik Islam Hindia Belanda. Jakarta: LP3ES: 23-24, pp. 27-34.

Yusuf, Slamet Effendy., Syam, Mohamad Ichwan and Mas'udi, Masdar Farid. (1983). Dinamika kaum Santri: Menelusuri Jejak dan Pergolakan Internal NU. Jakarta: CV. Rajawali. 
Social Capital: Strategy of Takmir of Jogokariyan Mosque on Developing the Worshipers 